\title{
Language barrier, funding, communication and time management problems found in the Medical Journal of Indonesia, 1995 - 2001
}

\author{
Isnani A Suryono ${ }^{*}$, Jeanne A Pawitan*, Abdul B Saifuddin ${ }^{* *}$
}

\begin{abstract}
Abstrak
Tujuan penelitian ini adalah untuk menganalisa masalah dalam pengelolaan majalah ilmiah kedokteran berstandar internasional, dan menilai kemajuan yang dicapai selama 7 tahun terakhir. Penelitian ini adalah penelitian retrospektif deskriptif yang dilakukan di MJI. Data yang digunakan sebagai parameter adalah: jumlah artikel yang masuk dan fakultas-asal penulis artikel, jumlah artikel yang diterima dan ditolak, sebab/kriteria penolakan, kualifikasi mitra-bestari dan editor, lama pemrosesan artikel, dan ketepatan waktu sesuai yang telah dijadwalkan oleh MJI. Untuk itu, semua artikel dari Januari 1995 - Januari 2001 dievaluasi. Selain itu, masalah yang ditemui dicatat. Ditemukan berbagai masalah yaitu: jumlah artikel yang masuk terbatas, yang mungkin disebabkan oleh hambatan bahasa, menurunnya jumlah sirkulasi karena terbatasnya sumber keuangan, dan masalah komunikasi karena senioritas penulis. Selain itu, terjadi peningkatan waktu pemrosesan rata-rata, yang mungkin disebabkan oleh terbatasnya waktu yang disediakan pengelola untuk MJI. Selama tahun 1995-1997, jumlah artikel yang berasal dari penulis nasional dibanding internasional adalah 101 banding 16, sedangkan antara 1998-2000 ialah 124 banding 84. Antara tahun 1999-2001, $\pm 26,4 \%$ dari artikel yang masuk ditolak, dengan alasan penolakan yang utama adalah dangkalnya materi dan analisis data yang tidak memadai. Dalam hal kualifikasi editor, terdapat peningkatan jumlah PhD dan Profesor, dan dalam hal pemrosesan makalah, waktu yang dibutuhkan \pm 1,5 kali waktu yang dijadualkan. Tampaknya terdapat 4 masalah utama, yaitu: hambatan bahasa, pendanaan, dan masalah dalam komunikasi dan manajemen waktu. Dalam hal jumlah artikel yang masuk, dan kualifikasi editor dan mitra bestari, walaupun tidak menyolok, terjadi sedikit perbaikan, sedangkan waktu pemrosesan rata-rata kurang lebih tetap sama, dan masih perlu perbaikan dalam hal ketepatan jadual penyelesaian penyuntingan. (Med J Indones 2001; 10:252-8)
\end{abstract}

\begin{abstract}
The objective of this study is to assess the problems encountered in the management of Medical Journal of Indonesia and whether any progress has been achieved during the past 7 years. A retrospective descriptive study was done in the MJI. Available data used as parameters were: number of articles submitted and author's home institution, number of articles submitted and rejected, cause/criteria of rejection, qualification of reviewers and editors, duration of manuscript processing, and whether pre-scheduled time is met in the Med J Indones. For this purpose, all manuscripts from January 1995 -January 2001 were evaluated. In addition, recent problems encountered were noted. Problems encountered were limited supply of manuscript that might be due to language barrier, decrease in circulation due to limited budget, communication problems due to seniority, and increase in average processing time that might be due to restriction in the time allocated for MJI. Number of articles submitted by authors originating from national versus foreign institutions in $1995-1997$ was 101 versus 16, and in $1998-2000$ were 124 versus 84 . Articles rejected were $\pm 26.4 \%$ (19992001 ) and the most frequent causes of rejection were insignificancy of substance and improper data analysis. As for the qualification of editors there was an increase in the number of PhDs and professors. Average processing time is approximately 1.5 times the scheduled time. It seems that the 4 main problems encountered were (I) Language barrier, (2) Funding, (3) Communication problems and (4) Time management; and though not impressive, there are definitely positive changes in the number of manuscripts submitted, qualification of editors and peer reviewers. Average processing time is about the same, and the prescheduled time of editing is yet to be met. (Med J Indones 2001; 10:252-8)
\end{abstract}

Keywords: language barrier, funding, communication problems, time management

\footnotetext{
* Department of Histology, Faculty of Medicine University of Indonesia, Jakarta, Indonesia

"* Department of Obstetrics and Gynecology, Faculty of Medicine University of Indonesia, Jakarta, Indonesia
}

The MJI (Med J Indones = Medical Journal of Indonesia) was founded in 1992 by a group of teaching staff of the Faculty of Medicine, University of Indonesia (FMUI) who were editors of the publisher of FMUI (Balai Penerbit FKUI). The main targest readers of MJI are the academic staff of 
state/private medical faculties throughout Indonesia. The mission is to penetrate the international scientific network in order to introduce the medical research in Indonesia to the global network.

Managing an 'international' medical journal in a non English speaking developing country is a challenging but most rewarding activity, which may be attributed to many typical situations that sometimes can be frustrating. Since English is not an official second language here, there were serious limitations of the articles submitted, especially at the beginning years. So during the first 2 years at least, we received articles both in English and bahasa Indonesia. Beginning in the $3^{\text {rd }}$ year, only manuscripts in English were accepted for publication in the MJI. Some of the articles received were researches done in conjunction with foreign institutions, and some came from foreign authors.

In earlier days, despite the continuous support from the official publisher of the faculty, it was really a problem even to cover the production cost, since sponsors and advertisements were scarce. In 1995 we won the $1^{\text {st }}$ batch and in 1998 , the $2^{\text {nd }}$ batch of URGE (University Research Graduate Education) grant from the ADB which covered $\pm 20 \%$ of production costs, and it encourages the editorial board to continue the journal's existence up till now where we are in our $10^{\text {th }}$ year.

From the beginning, it is impossible for the journal to employ professional editors with expertise in basic, clinical and epidemiological medical sciences, so the members in our editorial board are clinicians, basic medical scientists or clinical epidemiologists working part time as editors. As part-timers the time allocated to the journal depends heavily on the workload of the editors' main job.

This retrospective descriptive study was aimed to assess problems encountered and to evaluate the progress in every field, especially in manuscript processing in the MJI.

\section{METHODS}

Data on progress and problems were obtained from the Editor in Chief's reports of January 1998, and February 2001, and the MJI file records from 1995 2001. The data extracted were: number of articles submitted and principal author's home institution, number of articles submitted and rejected, causes/ criteria of rejection, qualification of reviewers and editors, duration of and whether pre-scheduled time of manuscript processing is met. The data were classified and presented as tables. Comparisons were made between journals published before 1997 and after.

\section{RESULTS}

Since 1992 we have changed our cover design several times, an executive secretary was employed since 1994, and a consultant in language was added during the period of 1995-1998. In 1997 the "instructions to authors" used were adjusted to the latest reference system of Vancouver. Since 2001, the table of content were rearranged according to type of articles, and an international editorial advisory board was added.

\section{Source of manuscripts and home institution of principal authors}

A continuous supply of manuscripts has not been established yet, despite the automatic membership of post-graduate students. This may be due to the fact that many of our competitors accept articles in Indonesian language. Supply of manuscripts, especially in the first few years, was extremely limited due to the language barrier. This condition forces the editorial board to act as manuscript hunters and translators as well. However as new volumes were produced, more manuscripts were submitted from national and even foreign institutions, as shown in Table 1.

\section{Number of acceptances and rejections of manuscripts and criteria of rejection}

One of the means to ensure the quality control is the using of peer reviewers for each manuscript, which was done in the MJI since 1992. In doing this, board of editors normally choose 2 peer reviewers considered relevant with the article substance. Shottd there be discordances between the 2 reviewers, the board of editors would make the final decision. A reviewer usually takes care of the subject content, scientific quality, methodology, and the structure of presentation, but several reviewers sometimes also do some of the language corrections, particularly concerning the clarity of presentation.

Number of manuscripts accepted and rejected and reasons of rejection are presented in Tables 2 and 3 below. 
Table 1. Number of manuscripts received and principal author's home institution from January 1995 - January 2001

\begin{tabular}{|c|c|c|c|c|c|c|c|c|}
\hline Authors' home institution & '95 & '96 & 97 & '98 & '99 & '00 & '01 & Number \\
\hline University of Indonesia (Jakarta) & 33 & 20 & 24 & 27 & 36 & 31 & 16 & 187 \\
\hline Other state universities & 5 & 6 & 8 & 5 & 2 & 1 & - & 27 \\
\hline Private universities. & - & 4 & 1 & - & 2 & 3 & 1 & 11 \\
\hline Subtotal: & 38 & 30 & 33 & 32 & 40 & 35 & 17 & 225 \\
\hline Foreign Institutions: & '95 & '96 & $' 97$ & '98 & '99 & '00 & '01 & Number \\
\hline 1. Japan & 3 & 1 & - & 3 & 1 & 4 & - & 12 \\
\hline 2. Singapore & - & 1 & - & 1 & - & - & - & 2 \\
\hline 3. India & - & 2 & 4 & 13 & - & 2 & 3 & 24 \\
\hline 4. Thailand & - & $=$ & 1 & 4 & - & - & - & 5 \\
\hline 5. Malaysia & - & - & - & 9 & - & - & - & 9 \\
\hline 6. Taiwan & - & & - & 1 & - & - & - & 1 \\
\hline 7. Vietnam & - & - & - & 5 & - & - & - & 5 \\
\hline 8. Hong Kong & - & - & - & 1 & - & - & - & 1 \\
\hline 9. Philippines & - & - & - & 1 & - & - & - & 1 \\
\hline 10. USA & - & 2 & - & 3 & 1 & 1 & - & 7 \\
\hline 11. Switzerland & - & - & - & 2 & - & - & - & 2 \\
\hline 12. Pakistan & - & - & - & 4 & - & - & - & 4 \\
\hline 13. Russia & - & - & - & 4 & - & - & - & 4 \\
\hline 14. Mexico & - & - & - & 3 & - & - & - & 3 \\
\hline 15. Canada & - & - & - & 4 & - & - & - & 4 \\
\hline 16. Australia & - & - & - & 3 & - & - & - & 3 \\
\hline 17. France & - & $\because$ & - & 2 & - & - & - & 2 \\
\hline 18. South Africa & - & - & - & 1 & - & - & - & 1 \\
\hline 19. U.K. & - & - & - & 3 & & - & - & 3 \\
\hline 20. Nepal & - & - & - & 直 & & - & - & t \\
\hline 21. Egypt & - & - & - & $i$ & - & - & - & $\vdots$ \\
\hline 22. Italy & - & - & & 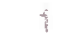 & - & - & + & I \\
\hline 23. Dutch & - & - & - & - & 1 & - & - & $\hat{\imath}$ \\
\hline 24. Germany & $\cdot$ & 2 & - & $=$ & - & - & 1 & 3 \\
\hline Subtotal: & 3 & 8 & 5 & 70 & 3 & 7 & 4 & 100 \\
\hline Total contributors & 41 & 38 & 38 & 102 & 43 & 42 & 21 & 325 \\
\hline
\end{tabular}

Table 2. Number of manuscripts accepted and rejected (MII vol. $\left.9^{2} 10\right)$

\begin{tabular}{|c|c|c|c|c|c|c|}
\hline \multirow{2}{*}{$\begin{array}{l}\text { Article } \\
\text { Type }\end{array}$} & \multicolumn{2}{|c|}{ Accepted } & \multicolumn{2}{|c|}{ Fejected } & \multicolumn{2}{|c|}{ Total } \\
\hline & $n$ & $\%$ & $\Pi$ & $\%$ & $n$ & $\%$ \\
\hline Basic Medical Research & 29 & 20.1 & $=$ & & 29 & 20.1 \\
\hline Clinical Research & 45 & 31.25 & 24 & 16.7 & 69 & 48 \\
\hline Epidemiology Research & 19 & 13.2 & 7 & 4.9 & 26 & 18.08 \\
\hline Preliminary report & 1 & $\begin{array}{r}13.2 \\
0.7\end{array}$ & 3 & & 承 & 2.7 \\
\hline Review & 9 & 0.7 & 3 & 2.1 & 13 & 9.0 .38 \\
\hline Case report & 2 & 6.25 & 4 & 2.7 & 2 & 1.4 \\
\hline \multirow[t]{2}{*}{ Brief communication } & 1 & 1.4 & & & 1 & 0.7 \\
\hline & & 0.7 & & & & \\
\hline Total & 106 & 73.6 & 38 & 26.4 & 144 & 100 \\
\hline
\end{tabular}

It is apparent that the types of articles rejected most were clinical research, and none of the basic medical researches was as yet rejected. 
Table 3. Reasons of manuscript rejection (MJI vol. 8-10)

\begin{tabular}{lcc}
\hline \multirow{2}{*}{ Reason for rejection } & \multicolumn{2}{c}{ Total } \\
\cline { 2 - 3 } & $\mathrm{n} / \Sigma$ & $\%$ \\
\hline Insignificancy of problem & $38 / 38$ & 100 \\
Poor methodology & $21 / 38$ & 55.3 \\
Poor implementation of research & $21 / 38$ & 55.3 \\
Improper data analysis & $38 / 38$ & 100 \\
Unclear data presentation & $29 / 38$ & 76.3 \\
Lack of originality & $24 / 38$ & 63.2 \\
\hline Total & 38 & 100 \\
\hline
\end{tabular}

If a manuscript is rejected, besides filling out the usual form of rejection criteria (Table 3), the reviewers are requested to provide the reasons why an article is unsuitable, some of these were:

- Obsoleteness: > >... were stated to be new, but the latest literature cited was of 1991 ( 7 years ago).

- Serious defect in methodology: $\gg \ldots$ the diagnosis should be set up only after ... test were done so in this case, a proper diagnosis were not established yet.

- Redundancy: $\gg$... the author writes too much on the matter of ... which in this case is irrelevant.

Way of citing and format of reference were once the most common mistakes made by the authors, but as time goes by, authors become more familiar with the Vancouver style of reference writing adopted by the MJI. When editors were in doubt on statistical analysis, they consulted the problems with other members who were experts in statistics.

After the decision on the acceptance of a manuscript has been made, the Deputy editor in chief appointed one of the editors to take charge of a certain article. The Editor in charge is responsible of editing and communicating the corrections, comments and suggestions from the reviewers to the author. Ideally the author discusses the matter directly with the editor, but more frequently they communicate by letters/fax/e-mail or even telephone. After the editing and setting process had been completed, the Editor in Chief then did the final checking before the manuscripts were sent to the publisher for printing.

\section{Qualification of peer reviewers and editors}

Members of the editorial board were recruited among teaching staff of the FMUI who were interested in medical writing. Though most of the members have never had any formal training as editors, efforts have been taken for the publication to meet the international standards. To improve the quality in journal editing by the editors, the MJI joined the Asia Pacific Scientific Editors Association (APSEA) whose main office is in Singapore. MJI participated 4 times in the workshop in medical editing held in Singapore the last one attended was in 1996. MJ also participated in the $1^{\text {st }}$ and $2^{\text {nd }}$ workshop in the Management of Scientific Journals held by the Indonesian Directorate General of Higher Education. In September 1997 two of the editors participated in the Congress on Biomedical Peer Review and Global Communications held in Prague, Czech's Republic.

Since 1997 some of the editors were promoted to higher academic position, so we have more professors and $\mathrm{PhDs}$. To keep up with globalisation, since 2001 we have internationalised our board of editors by adding 4 foreign editors, 2 from the USA, 1 from Japan, and 1 from Australia, and approximately 200 copies per issue were sent abroad, some through diplomatic mails. Starting volume 4 number 4 the MJI was introduced on the internet and the address is: http://www.lookup.hompages/72413/mii.htm

Academic degree of peer reviewers and editors at the beginning (1992), in the mid course of MJI life (1997) and recently (2001) are presented in Table 4.

Table 4. Qualification of peer reviewers and editors

\begin{tabular}{|c|c|c|c|c|c|c|c|c|c|}
\hline \multirow[t]{2}{*}{ Qualification } & \multicolumn{3}{|c|}{ Prof (\%) } & \multicolumn{3}{|c|}{$\mathrm{PhD} / \mathrm{DSc} / \mathrm{Dr}(\%)$} & \multicolumn{3}{|c|}{$\operatorname{MSc}(\%)$} \\
\hline & '92 & ' 97 & 01 & '92 & '97 & '01 & '92 & 97 & 01 \\
\hline $\begin{array}{c}\text { Peer } \\
\text { Reviewer }\end{array}$ & $\begin{array}{l}6 / 39 \\
(15) \\
\end{array}$ & $\begin{array}{c}14 / 42 \\
(33) \\
\end{array}$ & $\begin{array}{r}11 / 25 \\
(44) \\
\end{array}$ & $\begin{array}{l}7 / 39 \\
(18) \\
\end{array}$ & $\begin{array}{c}18 / 42 \\
(43) \\
\end{array}$ & $\begin{array}{r}11 / 25 \\
(44) \\
\end{array}$ & $\begin{array}{l}4 / 39 \\
(10) \\
\end{array}$ & $\begin{array}{l}5 / 42 \\
(12) \\
\end{array}$ & $\begin{array}{l}4 / 25 \\
(16) \\
\end{array}$ \\
\hline Editor & $\begin{array}{l}4 / 14 \\
(29) \\
\end{array}$ & $\begin{array}{r}5 / 14 \\
(36) \\
\end{array}$ & $\begin{array}{l}4 / 13 \\
(31) \\
\end{array}$ & $\begin{array}{l}3 / 14 \\
(21) \\
\end{array}$ & $\begin{array}{r}5 / 14 \\
(36) \\
\end{array}$ & $\begin{array}{l}7 / 13 \\
(54) \\
\end{array}$ & $\begin{array}{l}6 / 14 \\
(43) \\
\end{array}$ & $\begin{array}{c}6 / 14 \\
(43) \\
\end{array}$ & $\begin{array}{l}3 / 13 \\
(23) \\
\end{array}$ \\
\hline
\end{tabular}




\section{Duration of manuscript processing and comparison of scheduled versus actual length of time needed}

The length of time especially of the editing process varies greatly (Table 7). Despite the more sophisticated editorial board member, the editing time does not decrease (Table 6). The scheduled time for manuscript processing has in reality not been met, and the average time of processing is approximately 1.5 times the scheduled time (Table 5).

Table 5. Average time needed in manuscript processing before and after 1997

\begin{tabular}{|c|c|c|c|c|}
\hline Stages of process & \multicolumn{2}{|c|}{ Time schedule as planned (weeks) } & $\begin{array}{l}\text { Average time } \\
\text { (vol.4-6) }\end{array}$ & $\begin{array}{l}\text { Average time } \\
(\text { vol.7-9) }\end{array}$ \\
\hline Office: reviewer assignment & \multicolumn{2}{|c|}{0.5} & 0.7 & 0.8 \\
\hline Reviewing process & \multicolumn{2}{|c|}{$1-2$} & 2 & 2 \\
\hline $\begin{array}{l}\text { Office: editor appointing } \\
\text { Editing } \\
\text { Back to author } \\
\text { Office: typesetting } \\
\text { Publisher for printing }\end{array}$ & $\begin{array}{c}0.5 \\
2 \\
1 \\
2-3 \\
1\end{array}$ & 7.5 & 11.6 & 11.8 \\
\hline Total processing time & \pm 1 & & \pm 14.3 & 14.6 \\
\hline
\end{tabular}

Table 6a. Mean length of processing time of articles (MJI vol. 4-6)

\begin{tabular}{|c|c|c|c|c|}
\hline Stages of process & $\begin{array}{c}1995 \\
\text { (weeks) }\end{array}$ & $\begin{array}{c}1996 \\
\text { (weeks) } \\
\end{array}$ & $\begin{array}{c}1997 \\
\text { (weeks) }\end{array}$ & $\begin{array}{c}\text { Average time } \\
\text { (weeks) }\end{array}$ \\
\hline Office-reviewer assignment & 0.6 & 0.8 & 0.8 & 0.7 \\
\hline Reviewing & 2.0 & 1.9 & 2.2 & 2.0 \\
\hline Editing & 7.4 & 7.4 & 7.9 & 7.6 \\
\hline Office-setting -printing & 4 & 4 & 4 & 4 \\
\hline Total: & 14 & 14.1 & 14.9 & 14.3 \\
\hline
\end{tabular}

Table 6. Mean length of processing time of articles (MJI vol. 7-9)

\begin{tabular}{|c|c|c|c|c|}
\hline Stages of process & $\begin{array}{c}1998 \\
\text { (weeks) }\end{array}$ & $\begin{array}{c}1999 \\
\text { (weeks) }\end{array}$ & $\begin{array}{c}2000 \\
\text { (weeks) } \\
\end{array}$ & $\begin{array}{c}\text { Average time } \\
\text { (weeks) }\end{array}$ \\
\hline Office-reviewer assignment & 0.6 & 0.8 & 1 & 0.8 \\
\hline Reviewing & 2.2 & 1.8 & 1.9 & 2 \\
\hline Editing & 9 & 6.1 & 8.5 & 7.8 \\
\hline Office typesetting - printing. & 4 & 4 & 4 & 4 \\
\hline Total: & 15.4 & 12.8 & 14.2 & 14.6 \\
\hline
\end{tabular}

Table 7a. Range of time needed for editing process (MJI vol.4-6)

\begin{tabular}{ccc}
\hline Year & Range of editing time (weeks) & Average time (weeks) \\
\hline 1995 & $1.0-20$ & 6.4 \\
1996 & $0.4-36$ & 7.4 \\
1997 & $0.4-40$ & 7.9 \\
\hline
\end{tabular}

Table 7. Range of time needed for editing process (MJI vol. 7-9)

\begin{tabular}{ccc}
\hline Year & Range of editing time (weeks) & Average time (weeks) \\
\hline 1998 & $1.0-24$ & 9.0 \\
1999 & $0.4-16$ & 6.1 \\
2000 & $0.4-36$ & 8.5 \\
\hline
\end{tabular}




\section{Funding}

Due to limited budget, since volume 5 number 3 , the number of circulations has been lowered drastically from 5000 to 2500 copies/number and due to the monetary crisis in 1997, starting from volume 6, it has decreased further to 2000 copies /number. Funds gained from subscribers' fee up till now are still insufficient since most of the MJI are distributed free of charge. Since the last 3 years some of the staffs of departments of the FMUI, started subscribing and by 1999 the Dean of FMUI require that part of the tuition fee of post graduate students be allocated to the MJI and so they automatically become subscribers to the MJI.

\section{DISCUSSION}

When our journal was founded, it was named the 'Medical Journal of the University of Indonesia' (MJUI) and to gain more articles from all over the country we changed its name to the 'Medical Journal of Indonesia' (MJI). The change made was partly due to suggestions from reviewers of URGE. However it turned out that the change of name did not increase. manuscripts from institutions outside of FMUI, as seen in Table 1 where there were 24 national non FMUI manuscripts between '95-'97, and after '97 only 14 . The decrease in the number of manuscript submitted is perhaps due to the fact that since1997, most of the other major universities have established their own journals.

Though half of the editorial board members are still actively working for the journal since it was founded 10 years ago, every year some mutations take place due to retirement or other reasons. Since 1997, some of our editors were promoted to higher academic position, so we have more $\mathrm{PhDs}$ and Professors (Table 4), but it appears that the higher positions may have been associated with the increased load of work, which consequently causes a negative impact on the editors to cope with their job.

Besides the usual editing process activities, for foreign authors the Editor in charge is responsible of the Indonesian abstract. Sometimes due to deadlines, as in our case, the editor has to write the synopsis and/or the running title, since it would take more time if we tried to contact the author to resolve that matter. Depending on the manuscripts submitted, sometimes editors have to act also as reviewers. In the early days, due to language requirement, supply of manuscripts is limited, such that editors at the time also acted as manuscript hunters and occasional translators.

Up to the present the MJI has to compete with other medical journals published by state and private medical schools in Indonesia and also with professional journals published by associations of medical specialists; which are getting larger in number. Furthermore, the MJI has to be more selective in its acceptance of articles in an effort to guarantee the scientific quality. For this reason, as a means to ensure quality control of the manuscript submitted, the MJI uses peer reviewers who are experts from the FMUI and other medical faculties in Indonesia. List of reviewers are acknowledged at the end of each volume ( $4^{\text {th }}$ issue), and reviewing is done anonymously. All manuscripts accepted are considered to have passed the local ethical commission.

Data on the number of manuscripts accepted and rejected showed that $26.4 \%$ of the manuscripts rejected took place between volumes 8-10 (Table2). It certainly showed progress in the ability in manuscript selection compared to the earlier days, when the editors have to translate even rewrite some of the manuscripts and sometimes joined 2 issues (volume 1 issues no. $3 \& 4$ ) due to the lack of manuscripts submitted. In those days, we could barely get enough manuscripts for each issue, let alone reject some of the manuscripts submitted. Among the problems encountered during communication with authors was, seniority. More than once some authors got really upset that their writings were considered imperfect and in need of modifications and corrections (some even became so impatient that they withdrew their manuscript!). The editors had to do their best through their persuasive skill to make sure that the highly qualified yet imperfect manuscripts were not lost.

An impressive number of foreign providers of articles showed up by the end of year 1998 (Table 1 part 2). Those manuscripts were the articles prepared for the following year's first 2 editions, and were to be the special issues for some international congress.

Gradually, the quality of our editors' editing skills was improving. At least this was evident from one of the editors who had been granted a scholarship to attend a pre-congress course for editors in Prague in 1997. Though the length in the manuscript processing time has shown no progress, there has been an increase in quality of editing. This may be due to the fact that some of our editors have become a kind of 
editorial consultant and they became increasing y wanted whenever the faculty's publishing company needed an editor for some textbooks or monograph to be published. This phenomenon, although enhancing our journal's prestige, on the other hand is disadvantageous, as it is taking our prize editors' time away from us, sometimes too much!

Though not impressive, there are definitely positive changes in number of contribution after 1997 (Table 1) this might be due to the fact that we had won a prestigious award from URGE besides getting accredited as the best Indonesian scientific journal for the health field by the Directorate General of Higher Education, and hopefully due to the fact that we were becoming more popular among the expected target readers! Improvement in academic qualification of editors and peer reviewers (Table 4) does not imply the improvement of quality of editing and peer reviewing. Nonetheless, the improvement may add to the credibility of the journal and this might be among the reasons for winning the $2^{\text {nd }}$ batch of award from URGE.

Besides language and funding, some of the problems encountered were due to the fact that none of "the editorial board members is a full-timer, so that the rapidity and quality of editing, depends heavily on the workload of editors at an appointed time. Consequently, the length of editing time varies greatly (Tables 7a \& 7). Although, it might depend also to the author's responsiveness and the quality of authoreditor's communication, besides on the quantity of correction needed for a specific manuscript. Average processing time in volumes 7-9 (Table 6) compared to those in volumes 4-6 (table 6a) though insignificant, increased a little and both are \pm 1.5 times the scheduled time (Table 5).

Since the beginning, it has never been easy for the MJI to gain sponsors, which in Indonesia mostly are the pharmaceutical industries. It can be both a good and bad sign: the good is that probably most of our articles are pure, un-sponsored articles, in the sense that it is free from non-scientific interests. However, on the other hand, perhaps because we are not widely read by the target audience of those pharmaceutical producers, namely the more influential physicians! Fortunately, the Dean of FMUI came to the rescue and in 1999 he came up with a strategy that part of the tuition fee of the post-graduate students were allocated to the MJI. In this way, our post-grads automatically became subscribers to our journal. So, besides the benefit of the subscription fee, we also get to gain more future authors this way! For this rather unusual but very necessary assistance, the editors of the MJI extended their thanks and deepest gratitude.

In conclusion, we found that the 4 main problems encountered were (1) Language barrier, (2) Funding, (3) Communication problem and (4) Time management, and though not impressive there are definitely positive changes in number of manuscript submitted, qualification of editors and peer reviewers. On the other hand, average processing time is about the same and the prescheduled time of editing is yet to be met.

\section{Acknowledgements}

The writers wish to thank the executive secretary Ms. Lily Sasmito Notokusumo and Ms Maryati for the precious help with data collection and finding, to Drs. Bastaman Basuki and Sudigdo Sastroasmoro, for their help with table presentations and Dr. Rianto Setiabudy $\mathrm{PhD}$ for his patience and willingness to read this article extensively. Also for the many suggestions for the sake of clarity of presentation in this paper, the authors wish to extend their most heartfelt thanks.

\section{REFERENCES}

1. Editor in Chief's report of January 1998.

2. Editor in Chief's report of February 2001.

3. MJI file records of the January 1995 - January 2001 issues.

4. List of Reviewers MJI volume 1, 1992 - volunte 10, 2001.

5. Reviewer's form of recommendation and assessment. 